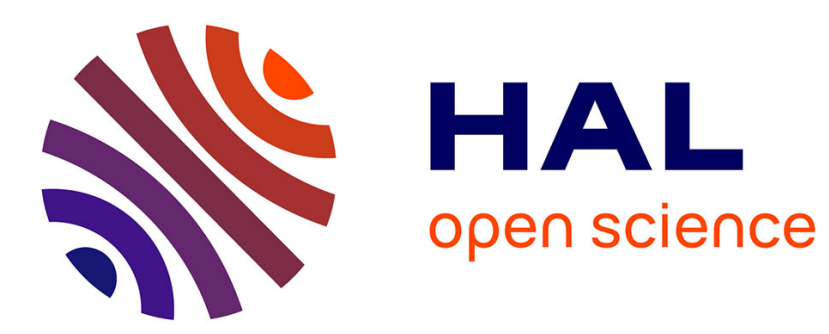

\title{
Structural and functional responses of leaf-associated fungal communities to chemical pollution in streams
}

Florent Rossi, Joan Artigas, Clarisse Mallet

\section{To cite this version:}

Florent Rossi, Joan Artigas, Clarisse Mallet. Structural and functional responses of leaf-associated fungal communities to chemical pollution in streams. Freshwater Biology, 2017, 62 (7), pp.1207-1219. 10.1111/fwb.12937 . hal-01808289

\section{HAL Id: hal-01808289 \\ https://hal.uca.fr/hal-01808289}

Submitted on 5 Jun 2018

HAL is a multi-disciplinary open access archive for the deposit and dissemination of scientific research documents, whether they are published or not. The documents may come from teaching and research institutions in France or abroad, or from public or private research centers.
L'archive ouverte pluridisciplinaire HAL, est destinée au dépôt et à la diffusion de documents scientifiques de niveau recherche, publiés ou non, émanant des établissements d'enseignement et de recherche français ou étrangers, des laboratoires publics ou privés. 
1 Structural and functional responses of leaf-associated fungal communities to chemical

2 pollution in streams

3

$4 \quad$ FLORENT ROSSI $^{*}, \downarrow$, JOAN ARTIGAS ${ }^{*, \downarrow}$, CLARISSE MALLET $^{*, \uparrow}$

5

6

* CNRS, UMR 6023, LMGE, 63177 Aubière, France.

$7{ }^{\mathrm{t}}$ Université Clermont-Auvergne, Laboratoire Microorganismes: Génome et Environnement, 8 BP 10448, F-63000 Clermont-Ferrand, France.

9

10

Corresponding author:

F. Rossi

Laboratoire Microorganismes : Génome et Environnement

1 Impasse Amélie Murat,

17 TSA 60026 , CS 60026

1863178 Aubière Cedex, France

Tel: +33473407453

Fax: +33473407670

E-mail: florent.rossi@univ-bpclermont.fr

Running head: Fungal community recovery from stream pollution.

Keywords: chemical stress, translocation, ligninolytic enzymes, aquatic fungi. 
1. In forested lotic ecosystems, organic matter decomposition processes, involving aquatic fungi and their ligninolytic activities play a key role. In this study, the relationship between realistic water chemical pollution (including nutrients, metals and pesticides) and the biomass, structure and enzyme activities of leaf-associated fungal communities was evaluated.

2. The experiment was performed through a microcosm approach by comparing fungal communities from a less-polluted upstream site to a more-polluted downstream site in the agricultural basin of the Auzon stream (Puy-de-Dôme region, Centre France). The resistance as well as the ability of these fungal communities to recover from pollution was also assessed through a translocation experiment.

3. Results showed a lower laccase activity and higher band richness in fungal communities from the downstream site comparing to the upstream site, that can partially be explained by the greater pesticide toxicity $(r=-0.50)$ and nutrient concentration $(r=-0.45$, dissolved organic carbon) of downstream waters.

4. Specifically, a negative relationship between laccase activity and nitrate concentration was observed, irrespectively of the studied site, whereas the relationship between nitrate and phenol oxidase/peroxidase appeared much weaker.

5. The translocation experiment evidenced i) a fast decrease in laccase activity concomitant with a shift in fungal structure after stress exposure, and ii) a recovery ability in terms of laccase activity and fungal community structure two weeks after stress removal.

6. The present study underlines the sensitivity of leaf-associated fungal communities in terms of laccase activity and community structure to variations in chemical stress, as well as their ability to recover once the stress is removed. This study highlights the potential use of laccase as indicators of stream water chemical pollution. 


\section{INTRODUCTION}

Low-order forested streams, representing more than $70 \%$ of the total stream network in most of European and US basins (Benda et al. 2004; Kristensen \& Globevnik 2014), are seasonally fueled with allochthonous organic matter coming from the riparian forest (Mninshall 1967). These organic matter inputs, mostly in the form of leaf litter, can represent up to $90 \%$ of the total organic matter in streams (Mninshall 1967; Triska et al 1970; Cummins 1974; Wallace \& Webster 1996). Consequently, the decomposition of leaf litter becomes a central process in these ecosystems since it i) intervenes in various biogeochemical cycles $(\mathrm{C}, \mathrm{P}, \mathrm{N}$ and $\mathrm{S}$; Webster \& Meyer 1997), ii) provides mineral nutrients to the entire stream food web (Gessner \& Chauvet 1994), and iii) returns $\mathrm{CO}_{2}$ to the atmosphere (Gholz et al. 2000). Leaf litter decomposition process in streams is performed by the action of both physical (abrasion, leaching and/or fragmentation) and biological factors; the latter including the action of microorganisms and macroinvertebrates (Mann 1975; Gessner, Chauvet \& Dobson 1999; Gaudes et al. 2009). While macroinvertebrates shredder taxa account for the major portion of the leaf mass loss in streams (Suberkropp \& Klug 1976), it has been estimated that microorganisms (including fungi and bacteria) can contribute up to $25-45 \%$ of the leaf mass loss, even if these estimations vary depending on leaf species and sites studied (Hieber \& Gessner 2002; Baldy et al. 2007). Although the contribution of each microbial group on leaf litter decomposition remains hard to evaluate, especially because of the difficulty to separate them from the leaf matrix, it is widely accepted that microbial decomposition is mostly attributed to the action of aquatic fungi (Krauss et al. 2011; Canhoto, Gonçalves \& Bärlocher 2016). Indeed, aquatic fungi (mostly the group of aquatic hyphomycetes) represent the major microbial biomass colonizing the leaf substratum (> 95\% of the total microbial biomass; Hieber \& Gessner 2002), and possess a large panel of extracellular hydrolytic and oxidative 
enzymes such as cellulases, hemicellulases and/or laccases (Abdullah et al. 1989;

Chandrashekar \& Kaveriappa 1991; Abdel-Raheem \& Ali 2004) capable to breakdown leaf structural compounds (e.g. cellulose, pectin, lignin).

In the actual scenario of streams pollution, mostly resulting from the anthropogenic activity occurring in the watersheds (i. e. agriculture, industry, urbanization), it has been proved that chemical pollution (by heavy metals, nutrients and xenobiotics) can threaten aquatic fungal communities and their decomposition abilities (Artigas et al. 2012), and by extension the entire ecosystem functioning (Duarte et al. 2008; Maltby, Brock \& van den Brink 2009). Amongst those pollutions, the effects of nutrients on aquatic fungal communities is certainly one of the most studied (Gessner et al. 1999). Although nutrient enrichment (by phosphorus and nitrogen) is commonly associated with increases in fungal biomass, diversity, and activity (Artigas, Romaní \& Sabater 2004; Hagen, Webster \& Benfield 2006; Magbanua et al. 2010), some studies also observed a negative effect of the nutrients, depending on the concentration and nature of the amendments (Baldy et al. 2002; Duarte et al. 2009b). For instance, high nitrate and ammonium concentrations in eutrophic streams have been shown to decrease fungal diversity and biomass, as well as their potential for decomposing leaf litter (Baldy et al. 2002; Duarte et al. 2009b). Effects of metals (cadmium, copper, and zinc) are commonly associated with reductions in fungal species richness, biomass, sporulation rates, and leaf decay rates (Krauss et al. 2001; Duarte, Pascoal \& Cassio 2009a; Zubrod et al. 2015). Recently, field experiments have attempted to assess the effects of pesticides on microbial litter decomposition in agricultural streams (Krauss et al. 2003; Rasmussen et al. 2012; Fernández et al. 2015). In most of the cases, the exposure to pesticides lead to declines in fungal species richness, concomitant with decreases in litter decay rates (Krauss et al. 2003; Rasmussen et al. 2012). More precisely, the type of the pesticide molecule as well as its mode of action would determine its potential impact on target and non-target leaf microorganisms 
1 (Maltby et al. 2009). This is the case of fungicides, being more toxic to aquatic fungi than other pesticides, due to their direct action on fungal physiology (Artigas et al. 2012; Fernández et al. 2015; Zubrod et al. 2015) but also indirectly affecting bacteria co-existing with fungi (Artigas et al. 2014). Up to now, however, the effects of multi-stressors, including pesticides and environmental stressors (e.g. temperature, droughts, nutrients...) in leafassociated fungal communities are weakly studied in the literature (Fernández et al. 2015). Besides, Piscart et al. (2011) did not find any correlation between pesticide pollution and microbial decay rates of leaves in a stream draining vineyard area in France. The absence of correlations was partially explained by the low temperatures recorded in their experiment which may have masked pesticides impact on microbial litter decomposition.

Translocation experiments are suitable approaches to assess such multi-stress impacts on stream microbial communities (including aquatic fungal communities). Indeed, this approach, which consist on transferring biological communities from polluted sites to pristine sites and vice versa (i. e. Ivorra et al. 1999; Proia et al. 2013), permits to identify resistance/resilience mechanisms set up by microbial communities to cope stress (Sridhar et al. 2005; Duarte et al. 2009a). At present, various studies have performed translocation experiments on periphytic biofilms (mostly targeting diatom communities dynamics; Ivorra et al. 1999; Morin et al. 2012). To our knowledge, two studies have performed translocation experiments to assess metal pollution on leaf-associated fungal communities (Sridhar et al. 2005; Duarte et al. 2009a) but none regarding the overall influence of nutrients, metals and pesticides. Studies on metals showed that copper, zinc, and manganese exposure stopped litter decomposition and declined sporulation rates. However, these studies also showed that fungal communities were able to recover when stress by metals was removed after translocation from a polluted site to a cleaner one. 
The present study investigates the sensitivity of leaf-associated fungal communities to

stream water pollution (including nutrients, metals, and pesticides) by comparing communities from upstream (less polluted) and downstream (more polluted) sites of an agricultural stream (the Auzon, Puy-de-Dôme region, Centre France). Our main objective is to assess the resistance and recovery abilities of leaf-associated fungal communities to stream water pollution using a translocation experiment in laboratory microcosms. As base hypothesis we presume that stream water pollution observed downstream (higher nutrients, metals, and pesticides concentrations) would promote shifts in the structure and activity of leaf-associated fungal communities comparing to communities from the upstream site (less polluted). As second hypothesis, we expected that chemical stress exposure due to translocation from upstream to downstream would lead to fungal communities similar to that of downstream in terms of both structure and activity. In the other hand, the proved recovery potential of leaf-associated fungal communities from single stressors suggest enough abilities in such communities to recover after stress removal during the translocation from downstream to upstream.

\section{MATERIALS AND METHODS}

\section{Study sites and preparation of fungal inoculums}

Leaf-associated fungal communities were obtained from the Auzon, a third-order forested stream draining a basin surface area of 6074 ha in the Puy-de-Dôme region (Centre France). Two study sites were selected for this work: a less-polluted upstream site (first order section) close to the river source $\left(45^{\circ} 41^{\prime} 30.0^{\prime \prime} \mathrm{N} 3^{\circ} 04^{\prime} 58.5^{\prime \prime} \mathrm{E}\right.$; Channonat) and a more-polluted downstream site (fourth order section) before the confluence of the Auzon with the Allier River (4543'30.3"N 3¹2'27.4"E; Cournon d'Auvergne). The riparian forest, mainly 
composed of Alnus glutinosa (L.) Gaertn and Corylus Avellana (L.) species, was well preserved at both upstream and downstream sites. However, streambeds were composed by gravel and cobbles in the upstream section and by sand in the downstream section. Land use variations throughout the watershed lead to an upstream section mostly occupied by forests and prairies and a downstream section devoted to agriculture (38\% of the total watershed surface area, mainly cereal crops) and some dispersed urbanizations (10\%). According to the report on phytosanitary molecules detection in surface waters from the Puy-de-Dôme region, the Auzon is one of the most herbicide-polluted streams, especially in its downstream section reaching concentration peaks of aminomethylphosphonic acid (AMPA), glyphosate, and Smetolachlor above $1 \mu \mathrm{g} \mathrm{L}^{-1}$ (Phyt'eauvergne 2014).

Fungal communities were obtained from the upstream and downstream sites of the Auzon in October 2014 using Alnus glutinosa (Alnus) leaf species as substratum. Freshly fallen Alnus leaves were harvested from the upstream site, dried $72 \mathrm{~h}$ at room temperature, and placed in a total of six bags ( $1 \mathrm{~mm}$ of mesh size), each containing $10 \mathrm{~g}$ of the pre-dried leaves. Three of these litter bags were placed upstream and the three others downstream in order to obtain fungal communities representative of the two sites. After three weeks of colonization in-stream, litter bags were retrieved and transported to the laboratory where leaves were cleaned with filtered $(0.2 \mu \mathrm{m})$ stream water, cut into small circles $(2 \mathrm{~cm}$ in diameter $)$ and placed in sterile $250 \mathrm{~mL}$ flasks (1 flask per bag). Each flask contained 10 leaf disks filled with $100 \mathrm{~mL}$ of filtered $(0.2 \mu \mathrm{m})$ stream water from each respective site (Gessner \& Chauvet 1993). Fungal mycelia growth and sporulation was achieved by incubations at $19{ }^{\circ} \mathrm{C}$ under agitation at $180 \mathrm{rpm}$ (Artigas et al, 2008). After $48 \mathrm{~h}$, water suspension and leaf disks that were crushed and well mixed, were transferred into sterilized flasks and used as inoculum for the subsequent microcosm experiment. 
In order to assess only the effect of stream water chemistry on microbial communities colonizing leaf litter, the experiment was performed in microcosm under controlled condition of temperature (room temperature, $19 \pm 0.1^{\circ} \mathrm{C}$ ), light (dark/light $13 \mathrm{~h}: 11 \mathrm{~h}, 846 \pm 50$ and 0 $\mu$ mol photons $\mathrm{cm}^{-2} \mathrm{~s}^{-1}$, respectively) and flow $\left(0.1 \mathrm{~L} \mathrm{~s}^{-1}\right)$. In total, six glass indoor stream channels $(1 \times \mathrm{w} \times \mathrm{d}=63 \mathrm{~cm} \times 11 \mathrm{~cm} \times 4 \mathrm{~cm})$, representing the upstream $(3$ replicate channels) and downstream (3 replicate channels) sites of the Auzon were set up in a thermoregulated room. Each channel was independent and connected to a separate $50 \mathrm{~L}$ tank through an aquarium pump (Newjet 1200, Newa, Italy) allowing water recirculation. Each tank was filled with river water taken directly from the corresponding study sites (upstream and downstream) of the Auzon. After one-day stabilization of microcosm devices with stream water, seven packs of pre-dried Alnus leaves (5 g dry weight per pack) were deployed in each channel, supplemented with $100 \mathrm{~mL}$ of the corresponding fungal inoculum described above. The first sampling was performed shortly after having released the fungal inoculum into the channel (week 0). The other samplings were performed weekly for a total of four weeks (weeks 1, 2, 3 and 4). The river water was replaced each seven days to avoid nutrient limitation and samplings were performed just before water replacement.

Translocation was performed in the middle of the experiment (after the sampling at week 2, the same day), 14 days after the beginning of the experiment) by transferring two randomly chosen leaf packs from i) upstream to downstream channels (Ups $\rightarrow$ Dws) and ii) downstream to upstream channels (Dws $\rightarrow$ Ups). One week after (7 days, week 3) the first translocated samples were sampled. Translocated samples were used to assess the impact (resistance) and the recovery (resilience) of leaf-associated fungal communities to stream water pollution. Fungal communities having remained permanently in upstream and downstream channels were monitored in parallel during translocation. 
At each sampling time (weeks $0,1,2,3$, and 4), one randomly selected leaf pack was sacrificed from each channel and leaf disks $(1 \mathrm{~cm}$ in diameter $)$ were obtained for further analyses on the fungal community structure (DGGE), ergosterol concentration, extracellular enzyme activities (laccase, peroxidase and phenol oxidase), leaf dry weight, and lignin content. While extracellular enzyme activity measurements were performed the same sampling date, samples for fungal community structure, ergosterol concentration and lignin content were stored frozen at $-20^{\circ} \mathrm{C}$ until analyses. Additionally, water samples from each channel were taken at each sampling time to determine nutrients (nitrate, phosphate, and dissolved carbon), multi-residues (including pesticides) and metals (cadmium, copper, manganese, zinc) concentrations.

\section{Water physical and chemical parameters}

In each stream channel, water temperature, dissolved oxygen, conductivity and $\mathrm{pH}$ were measured at each sampling time using portable probes (ProODO YSI, Cond340i WTW, pHMeter CG818, respectively). Soluble reactive phosphorus (Murphy \& Riley 1962) and nitrate concentrations (Nitrat-Test kit, Merck, Darmstadt, Germany) in water were measured spectrophotometrically. Total dissolved carbon (TDC), dissolved organic carbon (DOC) and inorganic carbon (DIC) as well as nitrogen concentrations were measured using a total organic carbon analyzer (TOC-vCPN, Shimadzu, Kyoto, Japan). In parallel, water samples taken directly from the river were sent to Laboratoire de Touraine (COFRAC agreement number 1-0677) for pesticide multi-residues and heavy metals analyses. Predicted toxicity of pesticides in water samples was estimated according to the toxic units $(T U)$ concept (Sprague 1971). $T U$ for each pesticide and metabolite compound was calculated according to the following equation: 


$$
T U=\frac{C i}{E C 50 i}
$$

1 Where $C_{i}$ is the actual concentration of the pesticide in the water sample and $E C_{50 i}$ is the

2 median acute effect of this pesticide inhibiting $50 \%$ of the growth rate of standard aquatic

3 microbial species. Predicted toxicity of the pesticide cocktail, noted as $\Sigma T U$ s, was also

4 calculated at both upstream and downstream sites for each week as the sum of all $T U$ for the

5 pesticides detected in a single water sample. Since toxicity data $\left(E C_{50}\right)$ for pesticides on

6 aquatic fungi are not available in the literature (Maltby 2009; Maltby et al. 2009), $E C_{50}$ values

7 of microalgae (Scenedemus subspicatus, Scenedesmus abundans, Pseudokirchneriella

8 subcapitata and Chlamydomonas angulosa) were used as surrogates (see Rasmussen et al.

9 2012).

\section{Biomass and structure of fungal communities}

Ergosterol concentration determination was used as proxy for fungal biomass in leaves (Gessner \& Schmitt 1996). Lipids were extracted from leaves (fifteen leaf disks per sample) after incubation in $0.14 \mathrm{M} \mathrm{KOH}$ methanol at $80{ }^{\circ} \mathrm{C}$ during $30 \mathrm{~min}$. Extracts were purified and concentrated using solid-phase extraction (tC18 cartridges, Sep-Pak Vac RC, 500 mg, Waters) and then analyzed by a high pressure liquid chromatography system (Lachrom L-7400, Merck-Hitachi, Tokyo, Japan) equipped with an ODS-2 Hypersil column $(250 \times 4.6 \mathrm{~mm}, 5$ $\mu \mathrm{m}$ particle diameter; Thermo Scientific, San Jose, CA, U.S.A.) and using methanol as the mobile phase at a flow rate of $1.4 \mathrm{~mL} \mathrm{~min}^{-1}$. Ergosterol was detected at $282 \mathrm{~nm}$ and quantified according to an ergosterol standard (ergosterol purity $\geq 95 \%$, Sigma-Aldrich, St. Louis, Missouri, USA) ranging from 0 to $200 \mu \mathrm{g} \mathrm{mL}^{-1}$. Results were expressed in $\mu$ g ergosterol per $\mathrm{g}$ of leaf dry mass (DM). 
Total DNA extraction was performed from 5 leaf disks per sample using the FastDNA SPIN Kit for soil (MP Biomedicals, Santa Ana, California, USA) following the manufacturer's instructions with some minor modifications. Briefly, two homogenization steps (FastPrep, speed 6.0 for 40 seconds) were applied instead of one in order to improve fungal mycelium extraction from the leaf matrix. Extracted DNA was quantified using a Nanodrop (Nanodrop ${ }^{\mathrm{TM}} 2000$, Wilmington, Delaware, USA), amplified by polymerase chain reaction (PCR) targeting the Internal Transcribed Spacer (ITS) region 2 of the fungal rRNA and then analyzed using denaturing gradient gel electrophoresis (DGGE) method. PCR mix was composed of $2.5 \mu \mathrm{l}$ of $\mathrm{MgCl}(50 \mathrm{mM}), 0.5 \mu \mathrm{l}$ of BSA $\left(50 \mathrm{mg} \mathrm{mL}^{-1}\right), 1 \mu \mathrm{L}$ dNTPs $(10$ $\mathrm{mM}), 0.3 \mu \mathrm{L}$ of Taq polymerase $\left(5 \mathrm{U} \mu \mathrm{L}^{-1}\right), 2 \mu \mathrm{L}$ of each primers $\left(10 \mathrm{pmol} \mu \mathrm{L}^{-1}\right), 5 \mu \mathrm{L}$ of $10 \mathrm{X}$ buffer and $4 \mu \mathrm{L}$ of DNA $\left(10 \mathrm{ng} \mathrm{L}^{-1}\right)$, completed with $\mathrm{H}_{2} \mathrm{O}$ to a final volume of $50 \mu \mathrm{L}$. Primers, purchased from MWG Biotech, were the forward ITS 3, with a GC tail attached in 5' (5'CGC CCG CCG CGC CCC GCG CCC GGC CCG CCG CCC CCG CCC CGC ATC GAT GAA GAA - 3') and the reverse ITS 4 (5'- TCC TCC GCT TAT TGA TAT GC 3') (White et al. 1990). PCR conditions were set at $95^{\circ} \mathrm{C}$ for 5 minutes, followed by 35 steps ( $30 \mathrm{~s}$ at 95 ${ }^{\circ} \mathrm{C}, 45 \mathrm{~s}$ at $55^{\circ} \mathrm{C}$ and 1 minute at $72{ }^{\circ} \mathrm{C}$ ) and a final elongation phase of 7 minutes at $72{ }^{\circ} \mathrm{C}$. PCR products were then checked on $1 \%$ agarose gel (size expected ranging 200-450 bp) and quantified using the DNA Quantification Kit, Fluorescence Assay (Sigma-Aldrich, SaintLouis, USA) before loading into DGGE. DGGE was run with 500 ng of PCR product per sample, using the TIGEK 2401-220 device (CBS Scientific, San Diego, North Carolina, USA) in $1 \mathrm{X}$ TAE buffer for $16 \mathrm{~h}$, with a temperature of $59{ }^{\circ} \mathrm{C}$ and a voltage of $90 \mathrm{~V}$. Gels contained $7.5 \%(\mathrm{w} / \mathrm{v})$ of polyacrylamide and a linear urea-formamide denaturing gradient ranging of $25 \%-48 \%(100 \%=7 \mathrm{M}$ urea and $40 \%(\mathrm{v} / \mathrm{v})$ formamide $)$. At the end of the electrophoresis, gels were stained in 1X TAE buffer containing 1/20000 dilution of Gel star (Lonza, Rockland, USA) and digitized using a BioSpectrumAC Imaging System (UVP, Upland, California, 
1 USA). DGGE bands profiles were then analyzed using the Gelcompare2 software (Applied

2 Maths, Belgium) in order to obtain the fungal band matrix, based on presence/absence of

3 bands from each sample. Using this matrix, a cluster analysis was performed to assess

4 homologies among experimental conditions tested.

5

\section{Mass loss and lignin determination in leaves}

Decomposition rates of Alnus leaves ( $k$ ) were evaluated from leaf mass loss. Leaf mass loss was surveyed between weeks 0 to 4 in the different experimental conditions. The percent loss in dry mass (DM, oven-weight after $48 \mathrm{~h}$ at $60{ }^{\circ} \mathrm{C}$ ) from ten leaf disks (pooled in one replicate sample) permitted to calculate decay rates using an exponential decay model: $M_{t}=M_{0} e^{-k t}$, where $M_{0}$ is the initial DM $(\mathrm{g}), M_{t}$ is the final DM $(\mathrm{g})$ at time $t$, and $k$ is the breakdown coefficient (Petersen \& Cummins 1974).

Lignin content in Alnus leaves was measured using the acetyl bromide procedure described by Iiyama \& Wallis (1988). Five leaf disks were digested with $2.5 \mathrm{~mL}$ of acetyl bromide solution in acetic acid $(25 \%, \mathrm{w} / \mathrm{w})$ at $70{ }^{\circ} \mathrm{C}$ for 30 minutes. Extracts were then transferred into $50 \mathrm{~mL}$ flasks and rinsed with a $15 \mathrm{~mL}$ acetic acid up to a final volume of 50 mL. Results were obtained spectrophotometrically and expressed as lignin percentage per leaf DM, using the following equation:

$$
\% \text { Lignin }=\frac{A}{\varepsilon \text { Lignin } \times l \times C} \times 100
$$

Where $\mathrm{A}$ is the absorbance of the sample at $280 \mathrm{~nm}, \varepsilon$ is the absorption coefficient for lignin $\left(\varepsilon_{\text {lignin }}=20 \mathrm{~g}^{-1} \mathrm{~L} \mathrm{~cm}^{-1}\right), 1$ is the path length of the beam in $\mathrm{cm}$ and $\mathrm{C}$ is the concentration of the sample in $\mathrm{g}$ of $\mathrm{DM} \mathrm{L}^{-1}$. 


\section{Extracellular enzyme activities}

2 Phenol oxidase (EC 1.14.18.1), peroxidase (EC 1.11.1.7), and laccase (EC 1.10.3.2) activities

3 were measured in leaf samples (three leaf disks per sample) using 3,4-Dihydroxy-L-

4 phenylalanine (L-DOPA) and 2,2'-Azino-bis(3-ethylbenzthiazoline-6-sulfonic acid) (ABTS)

5 commercial substrates analogues (Sigma-Aldrich, St. Louis, Missouri, USA). All enzyme

6 activities were conducted under saturating conditions of substrate (previously determined

7 from substrate saturating curves) and according to the protocols of Sinsabaugh, Osgood \&

$8 \quad$ Findlay (1994a) and Johannes \& Majcherczyk (2000). Phenol oxidase and peroxidase

9 activities assays consisted in dark incubations of 3 leaf disks per replicate at $19{ }^{\circ} \mathrm{C}$ under agitation in glass test tubes containing $2 \mathrm{~mL}$ of water from the corresponding channel with 2 $\mathrm{mL}$ of $1.5 \mathrm{mM}$ L-DOPA (final concentration) in acetate buffer ( $\mathrm{pH} 4.5$ ). Peroxidase activity assay received an addition of $0.2 \mathrm{~mL}$ of $0.3 \% \mathrm{H}_{2} \mathrm{O}_{2}$. After 1 hour incubation, spectrophotometric readings at $460 \mathrm{~nm}$ were performed for phenol oxidase and peroxidase using the Ultrospec 2000 (Pharmacia Biotech, Trowbridge, UK). Net peroxidase activity was obtained after subtraction of phenol oxidase activity. Laccase activity was determined from 3 leaf disks per replicate, following the oxidation of $2 \mathrm{~mL}$ ABTS ( $3 \mathrm{mM}$, final concentration) in $0.1 \mathrm{M}$ of citrate-phosphate buffer ( $\mathrm{pH} 4.5)$ with $2 \mathrm{~mL}$ of water from the corresponding channel at $19{ }^{\circ} \mathrm{C}$, in the dark and under agitation $(150 \mathrm{rpm})$ for $1 \mathrm{~h}$. Absorbance was then determined at $420 \mathrm{~nm}$. All enzyme activities were corrected by control, performed with water from the corresponding site (no leaf disks), and expressed in $\mu$ mol substrate $\mathrm{h}^{-1} \mathrm{~g}$ leaf $\mathrm{DM}^{-1}$.

\section{Data analyses}

Differences between upstream and downstream sites for water physical and chemical parameters (oxygen, conductivity, $\mathrm{pH}$, nutrients, metals, and pesticides) were evaluated by a 
two-way ANOVA assessing the sources of variation for the factors time (weeks 0 to 4 ) and site (upstream, downstream) as well as their interactions. Differences between fungal community descriptors (ergosterol concentration, fungal band richness and extracellular enzyme activities) and litter characteristics (lignin content) were assessed using a first twoway ANOVA on upstream and downstream samples for the whole experiment (factors time : weeks 0 to 4 ; factors condition : upstream and downstream) and a second two-way ANOVA on all samples at week 3 and 4 corresponding to the translocation experiment (factors time: week 3 and 4 ; factors condition : upstream, downstream, translocation upstream to downstream, and translocation downstream to upstream). All data were transformed using the Box Cox function prior to the ANOVA tests to meet assumptions of normality and homoscedasticity of data residuals (Box and Cox, 1964), and were complemented with post hoc multiple comparison tests (Tukey's test, $P<0.05$ ).

From the fungal fingerprints obtained after DGGE analyses, the fungal band presence/absence matrix was transformed to Euclidean distance, and fungal communities were classified by a joining tree analysis using the Ward's hierarchical clustering method (Ward 2 criterion). Moreover, two redundancy analyses (RDA) were performed to determine relationships between water chemical and fungal community parameters. As described for ANOVA tests, a first RDA ( $\left.\mathrm{RDA}_{\mathrm{UpDw}}\right)$ was performed on upstream and downstream samples for the whole experiment, whereas the second RDA ( $\left.\mathrm{RDA}_{\text {Transloc }}\right)$ was performed on translocated and non-translocated samples at weeks 3 and 4 only. Briefly, fungal community descriptors data matrices were composed of 5 parameters: ergosterol concentration, fungal band richness and extracellular enzyme activities (phenol oxidase, peroxidase, and laccase). Water physico-chemical data matrices included 15 parameters: dissolved oxygen, $\mathrm{pH}$, conductivity, and concentrations of metals $(\mathrm{Cu}, \mathrm{Cd}, \mathrm{Mn}, \mathrm{Zn})$, phosphate, nitrate, dissolved carbon and nitrogen concentrations and $\Sigma T U$ s. Lignin percentage in leaves was also included 
1 in the above data matrix. All data from the matrices were transformed prior to analysis using

2 the Hellinger transformation according to Legendre \& Gallagher (2001), and a forward selection was performed to select water chemical parameters significantly correlated with fungal community descriptors using a Monte Carlo permutation test (anova.cca function, 999 unrestricted permutations, $P=0.05)$.

All statistical analyses were computed using the R software, and RDA as well as related methods were performed using the Vegan package (http://cran.r-project.org/).

\section{RESULTS}

\section{Physical and chemical characteristics of stream water}

A total of 17 pesticide compounds (14 herbicides, 2 insecticides, and 1 fungicide) were detected in water samples from the Auzon stream (Table 1). Overall, pesticides displayed relatively low concentrations (below $0.05 \mu \mathrm{g} \mathrm{L}^{-1}$ ) except for the herbicide glyphosate and its metabolite the aminomethylphosphonic acid (AMPA) (ranging 0.10-1.40 $\mu \mathrm{g} \mathrm{L}^{-1}$, irrespectively of the studied site), the aminotriazole and the diuron. While only three molecules were detected at the upstream site (glyphosate, AMPA, and lindane), the whole 17 pesticide compounds were detected downstream. Potential pesticide toxicity calculations, represented as the $\Sigma T U$ s, were on average (weeks 1 to 4 ) thirty times higher downstream $\left(35.96 \times 10^{-3} \pm 4.78 \times 10^{-3}\right)$ compared to upstream $\left(1.14 \times 10^{-3} \pm 0.39 \times 10^{-3}\right)$ (ANOVA, Site effect, $P<0.0001)$. This higher pesticide toxicity observed downstream can be attributed to both the number of pesticide compounds and the presence of diuron $\left(T U=2.06 \times 10^{-2}\right)$, oxadiazon $\left(T U=1.81 \times 10^{-3}\right)$ and terbutryne $\left(T U=3.13 \times 10^{-3}\right)$, contributing to the highest $T U$ observed downstream (Table 1). In addition, heavy metals ( $\mathrm{Cu}, \mathrm{Zn}, \mathrm{Mn}, \mathrm{Cd})$ displayed very low concentrations at both sites (Table 1) though their concentrations were significantly 
1 higher downstream compared to upstream (ANOVA site effect, $P<0.05$ ). Conductivity, $\mathrm{pH}$,

2 dissolved carbon (total and organic), and phosphate concentrations were also greater at the downstream site (ANOVA, site effect, $P<0.001$ for each parameter; Table 1 and Figure 1.1 and 1.2). Conversely, no differences were observed for total nitrogen and nitrate concentrations between sites (ANOVA, site effect, $P=0.1210$ and $P=0.1197$ respectively). More precisely, average nitrate concentrations were $0.51 \pm 0.04 \mathrm{mg} \mathrm{L}^{-1}$ and $0.53 \pm 0.04 \mathrm{mg} \mathrm{L}^{-}$

${ }^{1}$ in upstream and downstream channels, respectively (Figure 1.2). At week 2, $\mathrm{N}_{-} \mathrm{NO}_{3}{ }^{-}$ concentration peaked up to $0.70 \pm 0.10 \mathrm{mg} \mathrm{L}^{-1}$ upstream and $0.78 \pm 0.09 \mathrm{mg} \mathrm{L}^{-1}$ downstream (ANOVA time effect, $P<0.0001$ ).

\section{Litter decomposition rates and lignin content}

Decay rates of Alnus leaves calculated between weeks 0 and 4 were similar between downstream $\left(0.0162\right.$ day $\left.^{-1}\right)$ and upstream $\left(0.0101\right.$ day $\left.^{-1}\right)$ sites, as well as after translocation experiments, although no statistical analysis were performed. Besides, lignin content in Alnus leaves (data not shown) decreased from $10.45 \pm 1.39 \% \mathrm{DW}$ (week 0) to $4.30 \pm 0.52 \% \mathrm{DW}$ (week 4) upstream, representing a loss of 58\%. Downstream, lignin loss from leaves appeared lower than upstream (29\%) with values ranging from $8.20 \pm 0.79 \% \mathrm{DW}$ (week 0) to $5.82 \pm$ $1.63 \% \mathrm{DW}$ (week 4). Specifically, the major decrease in lignin content from leaves was observed at week 2 in upstream and downstream samples (ANOVA, time effect, $P<0.0001$ ). However, no effects of translocation were observed in lignin loss from leaves.

\section{Biomass and structure of fungal communities}

Ergosterol concentration in Alnus leaves showed values ranging from $80.25 \pm 11.45 \mu \mathrm{g} \mathrm{gDM}^{-1}$ to $417.37 \pm 24.56 \mu \mathrm{g} \mathrm{gDM}{ }^{-1}$ upstream and $61.84 \pm 2.79 \mu \mathrm{g} \mathrm{gDM}{ }^{-1}$ to $321.87 \pm 84.24 \mu \mathrm{g}$ $\mathrm{gDM}^{-1}$ downstream (Figure 2.1). The major shifts in ergosterol concentrations were between 
week 0 and week 1 (Tukey's test, $P<0.0001$ ), evidencing the colonization phase of Alnus leaves by fungi. No significant differences were observed in ergosterol concentration between upstream and downstream sites during the four weeks of study (Tukey's test, $P>0.05$ ), but concentrations tended to be slightly higher upstream. Translocation did not have any effects on ergosterol concentration (Figure 2.2).

Fungal band richness tended to increase from weeks 0 to week 4 (ANOVA, $P<0.05$ ) in both upstream (from $21 \pm 1$ to $44 \pm 1$ band) and downstream (from $36 \pm 1$ to $49 \pm 1$ band) samples, evidencing a fungal species succession on leaves. However, fungal band richness was on average (weeks 0 to 4 ) higher in downstream samples $(S=41 \pm 1)$ compared to upstream samples $(S=34 \pm 3$, Tukey test, Site effect, $P<0.05)$. Moreover, fungal band richness responded to both translocations (Dws $\rightarrow$ Ups and Ups $\rightarrow$ Dws), displaying samples with intermediary values (Tukey's test, $P>0.05$; Table 2).

Cluster analysis, performed on fungal community presence/absence matrix, showed a sample ordination, first by time and second by site (Figure 3). Effects of translocation on fungal community structure were perceptible at week 3 , and characterized by the splitting of translocated samples from their origin, despite still being in the same cluster. However, such effects became more evident at week 4. After stress removal (Dws $\rightarrow$ Ups translocation, week 4) translocated samples tended to form a separate cluster with those of upstream (less polluted site) and to separate from those of downstream (site of origin). Conversely, after stress exposure (Ups $\rightarrow$ Dws translocation, week 4) translocated samples tended to form a separate cluster with those of downstream (more polluted site) and to separate from those of upstream (site of origin, Figure 3).

\section{Enzymatic activities}


1 Peroxidase and phenol oxidase activities measured in Alnus leaves were not different between upstream and downstream samples (Tukey test, $P>0.05$ ) (Figure 4A1, B1), though a clear time effect was observed in both activities (ANOVA, time effect, $P<0.0001$ ). Time effects were characterized by peaks of activity at week 2 , multiplying by two-to-four the basal activity values recorded at the other sampling times in both upstream and downstream samples (Figure 4A1, B1). Translocation of leaves had no effect on the above mentioned enzyme activities (figure 4A2, B2).

In contrast, laccase activity showed differences between sites (Tukey's test, site effect, $P$ $<0.0001$ ), with higher average values (weeks 0 to 4$)$ in upstream fungal communities (1.84 \pm $\left.0.29 \mathrm{UgDW}^{-1} \mathrm{~h}^{-1}\right)$ comparing to those from downstream $\left(0.39 \pm 0.12 \mathrm{UgDW}^{-1} \mathrm{~h}^{-1}\right.$, Figure 4C1). Laccase activity also showed significant differences over time, especially at week 2 , where a 3 to 5 times drop of activity in upstream samples was observed (ANOVA, time effect, $P<0.0001)$. Concerning translocation experiments, after stress exposure $(\mathrm{Ups} \rightarrow$ Dws translocation, week 4) samples displayed an intermediate state, characterized by a decrease in laccase activity compared to upstream samples (samples of origin) and approached to the activity recorded in downstream samples at the same date (Tukey's test, $P<0.05$, Figure 4C2). Similarly, after stress removal (Dws $\rightarrow$ Ups translocation, week 4) translocated samples displayed an increase in laccase activity, reaching values similar to those from the upstream samples (Tukey's test, $P<0.05$ ).

\section{Relationship between water chemistry and fungal community parameters}

$\mathrm{RDA}_{\mathrm{UpDw}}$, performed with upstream and downstream samples between weeks 0 to 4 (Figure 5.1), displayed two axes representing $85.97 \%$ of the total variance explained by biological and environmental descriptors. The first Axis (RDA1 explaining $70.38 \%$ of the variance) was 
mainly correlated with nitrate concentration $(r=0.76)$ characteristic of samples at week 2 located in the right up corner of the $\mathrm{RDA}_{\mathrm{UpDw}}$ (peak of nitrate concentration), and coincided with high phenol oxidase and peroxidase activities, but low laccase activity. The second axis (RDA 2 explaining $15.59 \%$ of the variance) appeared mostly linked with heavy metals concentration $(\mathrm{Zn}, \mathrm{r}=-0.45)$ and pesticides toxicity $(T U, \mathrm{r}=-0.46)$, characteristic of samples from the downstream site showing higher values of fungal band richness and lower ergosterol concentrations. In contrast to the $\mathrm{RDA}_{\mathrm{UpDw}}$, the $\mathrm{RDA}_{\text {Transloc }}$ displayed two axes representing a much lower percent of the total variance $(46.46 \%)$. Here, only nitrate concentration (NO3) was retained by the permutation test as explicative of the variance in biological descriptors (Figure 5.2). Again, the first axis (RDA1 explaining $38.88 \%$ of the variance) was mainly correlated with nitrate concentration $(r=-0.59)$, but here coinciding with low rates of the three ligninolytic activities (laccase, phenol oxidase and peroxidase). Specifically, samples translocated from the downstream site to the upstream site at week 4 appeared in the right up corner of the RDA, and displayed low nitrate concentrations but high ligningolytic activities. In addition, fungal band richness appeared also negatively related to the nitrate concentration in water.

\section{DISCUSSION}

Despite confinement effects due to our microcosm approach performed under controlled conditions (temperature, light and flow), the obtained decay rates of Alnus glutinosa leaves appeared similar between sites (0.0101-0.0162 day $\left.{ }^{-1}\right)$ and were in the same range of that found in field experiments $\left(\left(\mathrm{k}=0.0054 \mathrm{day}^{-1}\right)\right.$ Chauvet 1987; $\left(\mathrm{k}=0.0161 \mathrm{day}^{-1}\right)$ Canhoto \& Graça 1996; $\left(\mathrm{k}=0.035 \mathrm{day}^{-1}\right)$ Hieber \& Gessner 2002). Only water, supplied to upstream and downstream leaf-associated fungal communities, was different, coming from the two different sites of the Auzon stream. Therefore, differences observed in terms of ligninolytic activity and 
structure of fungal communities responsible of Alnus leaves decomposition can be essentially attributed to variations in stream water chemistry. Among all chemical parameters measured in the stream water, nitrate concentration was tightly related to ligninolytic activities expression in fungal communities.

As expected, the Auzon appeared as a contaminated stream (Phyt'eauvergne 2014, Water agency, 2003). While DOC concentrations categorized its upstream and downstream sites in two different class of quality according to the water agency classification system (respectively poor and bad), nutrients $\left(\mathrm{NO}_{3}, \mathrm{PO}_{4}\right)$ and pesticides categorized the two sites into the same "good" class of quality (Table 1). Despite such small differences in terms of water quality between sites, upstream water led to microbial communities with higher laccase activity and a lower fungal band richness comparing to those grown in downstream water. Besides, no differences in fungal biomass (ergosterol concentration) between communities were observed. The influence of stream water chemistry on the microbial community descriptors was also supported by the translocation of leaves from upstream to downstream waters (stress exposure) which induced a sharp decrease in laccase activity concomitant with changes in the structure of the fungal community, but again without influence on fungal biomass. These results seems to support the "stress gradient" hypothesis proposed by Niyogi et al (2002), stating that biodiversity has a low threshold of response to a stress, whereas biomass and function remains stable but decrease only under high stress. However, laccase activity appeared to be very sensitive to water chemical stress.

Ligninolytic activities from fungal communities colonizing Alnus leaves were the most sensitive parameters to nitrate variations in our study. Indeed, nitrogen effect (including nitrate), have already been observed in other studies working on microbial communities from forest soils (Gallo et al. 2004; Baldrian 2006; Sinsabaugh 2010) and streams (Artigas et al. 2004). Despite the fact that ligninolytic activity regulation is still unclear, several studies 
reported negative correlations between nitrogen and both laccase, phenol oxidase and peroxidase activities, as observed in the second RDA (RDA Transloc $)$ of our study. However, our study showed also that after a two-fold increase of nitrate concentrations probably resulting from the rainfall event occurring at week 2, laccase activity tended to be inhibited (Pearson, $r$ $=-0.497, P<0.05)$, whereas peroxidase and phenol oxidase activities tended to be stimulated (Pearson, $\mathrm{r}=0.807$ and $\mathrm{r}=0.549$ respectively, $P<0.05, \mathrm{RDA}_{\mathrm{UpsDws}}$, Figure 5.2). The fact that ligninolytic activities responded differently to the nitrate increase is surprising. Usually, they evolve in the same manner, since laccases represent one of the largest class of phenol oxidases (Baldrian 2006; Sinsabaugh 2010). Generally, phenol oxidases and peroxidase activities are assayed using L-DOPA as substrate, the latter activity being calculated as the incremental response relative to phenol oxidases (Sinsabaugh, Osgood \& Findlay 1994b; Sinsabaugh 2010), whereas laccase activities are assayed using a more specific substrate: the ABTS ((Baldrian 2006; Junghanns et al. 2009)). Consequently, the differential relationships obtained between ligninolytic activities and nitrate concentration can be due to the choice of two different substrates for activity assays (Bach et al. 2013). Besides, the antagonistic results between laccase and the other two ligninolytic activities can also reflect the effect of translocation in microbial communities. Indeed, $\mathrm{RDA}_{\mathrm{UpsDws}}$ was performed on upstream and downstream samples over the four weeks of the experiment, whereas $\mathrm{RDA}_{\text {Transloc }}$ was performed on week 3 and 4 only. Consequently, the greater ligninolytic activities of translocated samples at week 4 (right up corner of the $\mathrm{RDA}_{\text {Transloc }}$ ) may reflect a transient response of communities to the translocation from the more polluted to less polluted site. Altogether, our results suggest that laccase activity is more sensitive to nitrate than phenol oxidase and peroxidase activities.

Site effects were also observed on laccase activity, with higher values upstream compared to downstream. Here, differences were neither explained by nitrate concentrations nor by 
differences in fungal biomass (ergosterol concentration) since no differences were observed between sites. These observations suggest that other factors may be involved in laccase activity regulation. We observed a negative correlation between dissolved organic carbon (DOC) and laccase activity (Pearson, $\mathrm{r}=-0.45, P<0.05$ ) as well as between Toxic Units (TU) and laccase activity (Pearson, $\mathrm{r}=-0.50, P<0.05$ ). As suggested in others studies, we hypothesized that both DOC quantity and quality (Elisashvili et al. 2006; Mikiashvili et al. 2006; Romaní, Artigas \& Ylla 2012) or the presence of some pesticide compounds could be important in laccase activity regulation (Zapp et al. 2011; Oliveira et al. 2013). Alternatively, shifts in fungal communities structure, highlighted by changes in fungal band richness, can partially explain the differences in laccase activity observed between sites and after translocation (Treton, Chauvet \& Charcosset 2004; Frey et al. 2004; Osono 2007). When looking at the fungal band absence/presence matrix, fungal species specific of the upstream fungal communities were not found in the downstream communities. Selection and/or shifts in dominance between species can be due to changes in water chemistry. As reported by AbdelRaheem \& Shearer (2002) and Abdel-Raheem \& Ali (2004) in culture experiments, not all aquatic fungal species have shown the ability to produce all types of ligninolytic enzymes. Besides, since laccases have an indirect role in carbon uptake by fungi from leaf litter (Baldrian 2006), the greater DOC concentrations (and perhaps different DOC quality) in water downstream may have led to the establishment of fungal species low-laccase producers, more competitive than some high-laccase procuders upstream. Our study reveals that stress by chemical pollution can induce shifts in the structure of fungal communities accompanied by decreases in laccase activity. However, no effect on the overall leaf mass loss was observed, suggesting a certain functional redundancy in these communities (Pascoal, Cássio \& Marvanová 2005) probably explained by compensation mechanisms in the organic matter degradation by extracellular enzymes. 
When stress by pollution was removed through the translocation from the polluted site (downstream) to the less polluted site (upstream), leaf-associated fungal communities displayed the ability to recover as stated in our base hypothesis. Both laccase activity and fungal community structure tended to get closer to that of fungal communities from upstream within 2 weeks. Such observations are consistent with other translocation studies, which showed that aquatic hyphomycetes communities were able to recover in terms of structure, decomposing activity (decay rates), and sporulation rates when translocated from highly metal-exposed sites to cleaner sites in about two to three weeks (Sridhar et al. 2005 in the field; Duarte et al. 2009a in microcosms). Regarding at the fungal band presence/absence matrix, this fast recovery in the structure of leaf fungal communities can actually mostly be explained by the disappearance of species in the translocated samples. Since fungal communities are very sensitive to nutrient variations in streams (Suberkropp \& Chauvet 1995; Bärlocher \& Corkum 2003), the combined effects of low nutrient concentrations in the upstream channels and the osmotic stress resulting from a sudden change of water chemistry (conductivity values were 2.7 times higher downstream than upstream) may have affected the dominance of certain fungal species from downstream communities.

Overall our study indicates that variations in stream water chemistry, resulting from anthropogenic activities in the watershed, induce changes in the structure and enzymatic pathway of leaf-associated fungal communities. However, recovery assessment allowed us to evidence an almost full recovery in these communities which encourages river restoration programs. But linking fungal community responses to stream water chemistry remains difficult considering the amount of stress compounds as well as their potential interactions (antagonistic, synergistic) and few $\mathrm{EC}_{50}$ data for pesticides on aquatic fungi are available in the literature, which decrease the reliability of pesticide risk assessment in these communities 
1 (Maltby et al. 2009). Thus, future researches should take into account aquatic fungi as species

2 sensitive to the chemical quality of stream waters.

3

4 ACKNOWLEDGEMENTS

5 This study was funded by the Fédération des Recherches en Environnement (UBP/CNRS FR

6 3467/INRA). We also thank Fanny Perriere for her help in the water chemical analyses. Florent

7 Rossi was funded by a PhD grant from the French Ministry of Higher Education and

8 Research.

9

10

11

12

13

14

15

16

17

18

19

20

21 


\section{REFERENCES}

Abdel-Raheem A.M. \& Ali E.H. (2004) Lignocellulolytic enzyme production by aquatic hyphomycetes species isolated from the Nile's delta region. Mycopathologia 157, 277-286.

Abdel-Raheem A. \& Shearer C.A. (2002) Extracellular enzyme production byfreshwater ascomycetes.

Abdullah S.K. \& others (1989) Extracellular enzymatic activity of aquatic and aero-aquatic conidial fungi. Hydrobiologia 174, 217-223.

Artigas J., Majerholc J., Foulquier A., Margoum C., Volat B., Neyra M., et al. (2012) Effects of the fungicide tebuconazole on microbial capacities for litter breakdown in streams. Aquatic toxicology 122, 197-205.

Artigas J., Romaní A.M. \& Sabater S. (2008) Effect of nutrients on the sporulation and diversity of aquatic hyphomycetes on submerged substrata in a Mediterranean stream. Aquatic Botany 88, 32-38.

Artigas J., Romaní A.M. \& Sabater S. (2004) Organic matter decomposition by fungi in a Mediterranean forested stream: contribution of streambed substrata. In: Annales de Limnologie-International Journal of Limnology. pp. 269-277. Cambridge Univ Press.

Bach C.E., Warnock D.D., Van Horn D.J., Weintraub M.N., Sinsabaugh R.L., Allison S.D., et al. (2013) Measuring phenol oxidase and peroxidase activities with pyrogallol, LDOPA, and ABTS: effect of assay conditions and soil type. Soil Biology and Biochemistry 67, 183-191.

Baldrian P. (2006) Fungal laccases-occurrence and properties. FEMS microbiology reviews 30, 215-242. 
Baldy V., Chauvet E., Charcosset J.-Y. \& Gessner M.O. (2002) Microbial dynamics associated with leaves decomposing in the mainstem and floodplain pond of a large river. Aquatic Microbial Ecology 28, 25-36.

Baldy V., Gobert V., Guerold F., Chauvet E., Lambrigot D. \& CHARCOSSET J.-Y. (2007) Leaf litter breakdown budgets in streams of various trophic status: effects of dissolved inorganic nutrients on microorganisms and invertebrates. Freshwater Biology 52, $1322-1335$.

Bärlocher F. \& Corkum M. (2003) Nutrient enrichment overwhelms diversity effects in leaf decomposition by stream fungi. Oikos 101, 247-252.

Benda L.E.E., Poff N.L., Miller D., Dunne T., Reeves G., Pess G., et al. (2004) The network dynamics hypothesis: how channel networks structure riverine habitats. BioScience 54, 413-427.

Canhoto C., Gonçalves A.L. \& Bärlocher F. (2016) Biology and ecological functions of aquatic hyphomycetes in a warming climate. Fungal Ecology 19, 201-218.

Canhoto C. \& Graça M.A. (1996) Decomposition of Eucalyptus globulus leaves and three native leaf species (Alnus glutinosa, Castanea sativa and Quercus faginea) in a Portuguese low order stream. Hydrobiologia 333, 79-85.

Chandrashekar K.R. \& Kaveriappa K.M. (1991) Production of extracellular cellulase byLunulospora curvula andFlagellospora penicillioides. Folia microbiologica 36, $249-255$.

Chauvet E. (1987) Changes in the chemical composition of alder, poplar and willow leaves during decomposition in a river. Hydrobiologia 148, 35-44.

Cummins K.W. (1974) Structure and function of stream ecosystems. BioScience 24, 631-641. 
1 Duarte S., Pascoal C., Alves A., Correia A. \& Cassio F. (2008) Copper and zinc mixtures induce shifts in microbial communities and reduce leaf litter decomposition in streams. Freshwater Biology 53, 91-101.

Duarte S., Pascoal C. \& CASsio F. (2009a) Functional stability of stream-dwelling microbial decomposers exposed to copper and zinc stress. Freshwater Biology 54, 1683-1691.

Duarte S., Pascoal C., Garabétian F., Cássio F. \& Charcosset J.-Y. (2009b) Microbial decomposer communities are mainly structured by trophic status in circumneutral and alkaline streams. Applied and environmental microbiology 75, 6211-6221.

Elisashvili V., Penninckx M., Kachlishvili E., Asatiani M. \& Kvesitadze G. (2006) Use of Pleurotus dryinus for lignocellulolytic enzymes production in submerged fermentation of mandarin peels and tree leaves. Enzyme and Microbial Technology 38, 998-1004.

Fernández D., Voss K., Bundschuh M., Zubrod J.P. \& Schäfer R.B. (2015) Effects of fungicides on decomposer communities and litter decomposition in vineyard streams. Science of The Total Environment 533, 40-48.

Frey S.D., Knorr M., Parrent J.L. \& Simpson R.T. (2004) Chronic nitrogen enrichment affects the structure and function of the soil microbial community in temperate hardwood and pine forests. Forest Ecology and Management 196, 159-171.

Gallo M., Amonette R., Lauber C., Sinsabaugh R.L. \& Zak D.R. (2004) Microbial community structure and oxidative enzyme activity in nitrogen-amended north temperate forest soils. Microbial Ecology 48, 218-229.

Gaudes A., Artigas J., Romaní A.M., Sabater S. \& Muñoz I. (2009) Contribution of microbial and invertebrate communities to leaf litter colonization in a Mediterranean stream. Journal of the North American Benthological Society 28, 34-43.

Gessner M.O. \& Chauvet E. (1993) Ergosterol-to-biomass conversion factors for aquatic hyphomycetes. Applied and environmental microbiology 59, 502-507. 
1 Gessner M.O. \& Chauvet E. (1994) Importance of stream microfungi in controlling breakdown rates of leaf litter. Ecology 75, 1807-1817.

Gessner M.O., Chauvet E. \& Dobson M. (1999) A perspective on leaf litter breakdown in streams. Oikos, 377-384.

Gessner M.O. \& Schmitt A.L. (1996) Use of solid-phase extraction to determine ergosterol concentrations in plant tissue colonized by fungi. Applied and Environmental Microbiology 62, 415-419.

Gholz H.L., Wedin D.A., Smitherman S.M., Harmon M.E. \& Parton W.J. (2000) Long-term dynamics of pine and hardwood litter in contrasting environments: toward a global model of decomposition. Global Change Biology 6, 751-765.

Hagen E.M., Webster J.R. \& Benfield E.F. (2006) Are leaf breakdown rates a useful measure of stream integrity along an agricultural landuse gradient? Journal of the North American Benthological Society 25, 330-343.

Hieber M. \& Gessner M.O. (2002) Contribution of stream detrivores, fungi, and bacteria to leaf breakdown based on biomass estimates. Ecology 83, 1026-1038.

Iiyama K. \& Wallis A.F.A. (1988) An improved acetyl bromide procedure for determining lignin in woods and wood pulps. Wood science and technology 22, 271-280.

Ivorra N., Hettelaar J., Tubbing G.M.J., Kraak M.H.S., Sabater S. \& Admiraal W. (1999) Translocation of microbenthic algal assemblages used for in situ analysis of metal pollution in rivers. Archives of Environmental Contamination and Toxicology 37, 1928.

Jiang N., Xiao D., Zhang D., Sun N., Yan B. \& Zhu X. (2009) Negative Roles of a Novel Nitrogen Metabolite Repression-Related Gene, TAR1, in Laccase Production and Nitrate Utilization by the Basidiomycete Cryptococcus neoformans. Applied and Environmental Microbiology 75, 6777-6782. 
Johannes C. \& Majcherczyk A. (2000) Laccase activity tests and laccase inhibitors. Journal of Biotechnology 78, 193-199.

Junghanns C., Pecyna M.J., Böhm D., Jehmlich N., Martin C., von Bergen M., et al. (2009) Biochemical and molecular genetic characterisation of a novel laccase produced by the aquatic ascomycete Phoma sp. UHH 5-1-03. Applied Microbiology and Biotechnology 84, 1095-1105.

Krauss G., Barlocher F., Schreck P., Wennrich R., Glasser W. \& Krauss G.-J. (2001) Aquatic hyphomycetes occur in hyperpolluted waters in Central Germany. Nova Hedwigia 72, $419-428$.

Krauss G.-J., Solé M., Krauss G., Schlosser D., Wesenberg D. \& Bärlocher F. (2011) Fungi in freshwaters: ecology, physiology and biochemical potential. FEMS microbiology reviews 35, 620-651.

Krauss G., Sridhar K.R., Jung K., Wennrich R., Ehrman J. \& Bärlocher F. (2003) Aquatic hyphomycetes in polluted groundwater habitats of Central Germany. Microbial ecology 45, 329-339.

Kristensen P. \& Globevnik L. (2014) European small water bodies. In: Biology and Environment: Proceedings of the Royal Irish Academy. pp. 281-287. JSTOR.

Legendre P. \& Gallagher E. (2001) Ecologically meaningful transformations for ordination of species data. Oecologia 129, 271-280.

Magbanua F.S., Townsend C.R., Blackwell G.L., Phillips N. \& Matthaei C.D. (2010) Responses of stream macroinvertebrates and ecosystem function to conventional, integrated and organic farming. Journal of Applied Ecology 47, 1014-1025.

Maltby L. (2009) 4: Heterotrophic Microbes. River Biota: Diversity and Dynamics, 45. 
1 Maltby L., Brock T.C. \& van den Brink P.J. (2009) Fungicide risk assessment for aquatic ecosystems: importance of interspecific variation, toxic mode of action, and exposure regime. Environmental science \& technology 43, 7556-7563.

Mann K.I.I. (1975) Detritus formation from eelgrass (Zostera marina L.): The relative effects of fragmentation, leaching, and decay. Limnol. Oceanogr 20, 924-934.

Mikiashvili N., Wasser S.P., Nevo E. \& Elisashvili V. (2006) Effects of carbon and nitrogen sources on Pleurotus ostreatus ligninolytic enzyme activity. World Journal of Microbiology and Biotechnology 22, 999-1002.

Mninshall G.W. (1967) Role of allochthonous detritus in the trophic structure of a woodland springbrook community. Ecology, 139-149.

Morin S., Lambert A.-S., Artigas J., Coquery M. \& Pesce S. (2012) Diatom immigration drives biofilm recovery after chronic copper exposure: Role of diatom immigration in recovery. Freshwater Biology 57, 1658-1666.

Murphy J. \& Riley J. (1962) A modified single solution method for the determination of phosphate in natural waters. Analytica chimica acta 27, 31-36.

Niyogi D.K., Lewis Jr W.M. \& McKnight D.M. (2002) Effects of stress from mine drainage on diversity, biomass, and function of primary producers in mountain streams. Ecosystems 5, 554-567.

Oliveira T.M., Barroso M.F., Morais S., de Lima-Neto P., Correia A.N., Oliveira M.B., et al. (2013) Biosensor based on multi-walled carbon nanotubes paste electrode modified with laccase for pirimicarb pesticide quantification. Talanta 106, 137-143.

Osono T. (2007) Ecology of ligninolytic fungi associated with leaf litter decomposition. Ecological Research 22, 955-974.

Petersen R.C. \& Cummins K.W. (1974) Leaf processing in a woodland stream. Freshwater biology 4, 343-368. 
1 Piscart C., Navel S., Maazouzi C., Montuelle B., Cornut J., Mermillod-Blondin F., et al. (2011) Leaf litter recycling in benthic and hyporheic layers in agricultural streams with different types of land use. Science of the Total Environment 409, 4373-4380.

Proia L., Osorio V., Soley S., Köck-Schulmeyer M., Pérez S., Barceló D., et al. (2013) Effects of pesticides and pharmaceuticals on biofilms in a highly impacted river. Environmental Pollution 178, 220-228.

Rasmussen J.J., Wiberg-Larsen P., Baattrup-Pedersen A., Monberg R.J. \& Kronvang B. (2012) Impacts of pesticides and natural stressors on leaf litter decomposition in agricultural streams. Science of The Total Environment 416, 148-155.

Romaní A.M., Artigas J. \& Ylla I. (2012) Extracellular enzymes in aquatic biofilms: microbial interactions versus water quality effects in the use of organic matter. Microbial Biofilms: Current Research and Applications. Caister Academic Press, Norfolk, 153-174.

Sinsabaugh R.L. (2010) Phenol oxidase, peroxidase and organic matter dynamics of soil. Soil Biology and Biochemistry 42, 391-404.

Sinsabaugh R.L., Osgood M.P. \& Findlay S. (1994a) Enzymatic models for estimating decomposition rates of particulate detritus. Journal of the North American Benthological Society, 160-169.

Sinsabaugh R.L., Osgood M.P. \& Findlay S. (1994b) Enzymatic models for estimating decomposition rates of particulate detritus. Journal of the North American Benthological Society, 160-169.

Sprague J.B. (1971) Measurement of pollutant toxicity to fish-III: Sublethal effects and “safe" concentrations. Water Research 5, 245-266. 
1 Sridhar K.R., Bärlocher F., Krauss G.-J. \& Krauss G. (2005) Response of aquatic hyphomycete communities to changes in heavy metal exposure. International review of hydrobiology $\mathbf{9 0}, 21-32$.

Suberkropp K. \& Chauvet E. (1995) Regulation of leaf breakdown by fungi in streams: influences of water chemistry. Ecology 76, 1433-1445.

Suberkropp K. \& Klug M.J. (1976) Fungi and bacteria associated with leaves during processing in a woodland stream. Ecology, 707-719.

Treton C., Chauvet E. \& Charcosset J.-Y. (2004) Competitive interaction between two aquatic hyphomycete species and increase in leaf litter breakdown. Microbial ecology 48, $439-446$.

Triska F.J. \& others (1970) Seasonal distribution of aquatic hyphomycetes in relation to the disappearance of leaf litter from a woodland stream.

Waldrop M.P. \& Zak D.R. (2006) Response of oxidative enzyme activities to nitrogen deposition affects soil concentrations of dissolved organic carbon. Ecosystems 9, 921933.

Wallace J.B. \& Webster J.R. (1996) The role of macroinvertebrates in stream ecosystem function. Annual review of entomology 41, 115-139.

Webster J.R. \& Meyer J.L. (1997) Organic matter budgets for streams: a synthesis. Journal of the North American Benthological Society 16, 141-161.

White T.J., Bruns T., Lee S., Taylor J.W. \& others (1990) Amplification and direct sequencing of fungal ribosomal RNA genes for phylogenetics. PCR protocols: a guide to methods and applications $\mathbf{1 8}, 315-322$.

Zapp E., Brondani D., Vieira I.C., Scheeren C.W., Dupont J., Barbosa A.M., et al. (2011) Biomonitoring of methomyl pesticide by laccase inhibition on sensor containing 

and Actuators B: Chemical 155, 331-339. Inorganic fungicides as routinely applied in organic and conventional agriculture can increase palatability but reduce microbial decomposition of leaf litter. Journal of Applied Ecology 52, 310-322.

7

8 9 
1 Table 1: Physical and chemical characteristics and pesticide compounds detected (Herbicides

$2(\mathrm{H})$, Insecticides (I) and Fungicides (F)) in the upstream and downstream waters of the Auzon

3 stream during the laboratory experiment. Values are means and $( \pm)$ standard errors of the five

4 sampling times for nutrients $(\mathrm{n}=15)$ and four sampling times for pesticides and heavy metals

$5 \quad(\mathrm{n}=12)$. Significant differences between sites (ANOVA, $P<0.05)$ are shown by an asterisk.

$6 T U$ calculation were based on $E C_{50}$ of Scenedemus subspicatus ${ }^{\text {a }}$, Pseudokirchneriella

7 subcapitata $^{\mathrm{b}}$, Scenedesmus quadricauda $^{\mathrm{c}}$, Scenedesmus abundans ${ }^{\mathrm{d}}$ and Chlamydomonas

8 angulosa $\mathrm{e}^{\mathrm{e}}$.

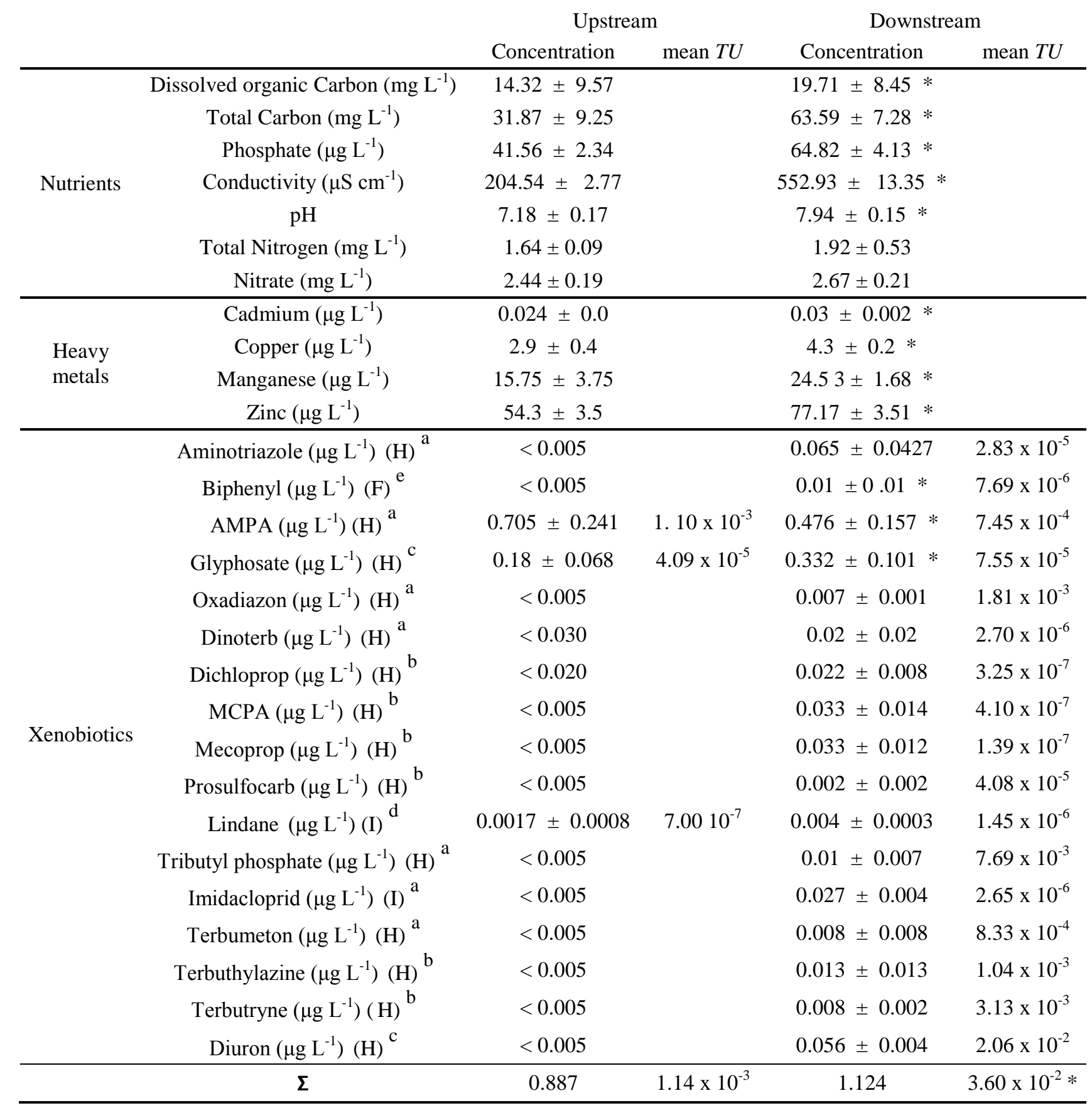


1 Table 2: Fungal band richness in leaf-associated fungal communities obtained during the

2 translocation experiment (translocated samples are highlighted in italics). Values are means

3 (weeks 3 and 4) \pm standard errors for each experimental condition. Significant differences

4 between conditions for each week are shown $(\mathrm{a} \neq \mathrm{b}$, Tukey's test, $P<0.05)$.

\begin{tabular}{|c|c|c|c|}
\hline \multirow{2}{*}{$\begin{array}{l}\text { Experimental } \\
\text { conditions }\end{array}$} & \multicolumn{3}{|c|}{ Time (weeks) } \\
\hline & 3 & & 4 \\
\hline Upstream & $20.67 \pm 0.33$ & $\mathrm{a}$ & $37.67 \pm 2.19 \quad \mathrm{a}$ \\
\hline$U p s->D w s$ & $25.33 \pm 0.67$ & $\mathrm{a}$ & $41 \pm 0.58$ \\
\hline Downstream & $36.33 \pm 1.20$ & $\mathrm{~b}$ & $49.33 \pm 1.20 b$ \\
\hline$D w s->U p s$ & $34.33 \pm 3.48$ & $\mathrm{~b}$ & $42.33 \pm 2.03 \mathrm{ab}$ \\
\hline
\end{tabular}




\section{FIGURE LEGENDS}

Figure 1: Dissolved inorganic (DIC) and organic (DOC) concentrations (1) as well as nitrate (NO3) and phosphate (PO4) concentrations (2) measured in the upstream (Ups) and downstream (Dws) site of the Auzon stream. Values are means and standard error $(n=3)$, and significant differences are show by brackets with asterisks for conditions and asterisks only for time (n.s. when not significant, Tukey's test, $P<0.05$ ).

Figure 2: Ergosterol concentration on Alnus leaves in upstream and downstream samples for the whole experiment (1) and in all samples after translocation (2). Values are means ( $\mathrm{n}=3)$ and standard errors for the four experimental conditions [upstream samples (Ups), downstream samples (Dws), samples translocated from control to polluted site (Ups->Dws) and samples translocated from polluted to control site (Dws->Ups)]. Significant differences between conditions for each week are shown by brackets with asterisks (n.s. when not significant, Tukey's test, $P<0.05)$.

Figure 3: Clustering analysis on the structure of the Alnus-associated fungal communities, representing the upstream samples (Ups), downstream samples (Dws), samples translocated from control to polluted site (Ups->Dws) and samples translocated from polluted to control site (Dws->Ups) during the four weeks of experiment. Clustering was obtained using the Ward method (Ward dissimilarity index) on fungal DGGE absence/presence matrix.

Figure 4: Values of the peroxidase (A), phenol oxidase (B) and laccase (C) activities measured in Alnus leaves in upstream and downstream samples for the whole experiment (1) 
1 and in all samples after translocation (2). Enzymatic activities are expressed as the amount of

2 2,3-dihydroindole-5,6-quinone-2-carboxylate (DIQC for peroxidase and phenol oxidase) and

3

4

5 oxidized 2,2'-azino-bis(3-ethylbenzothiazoline-6-sulphonic acid) (ABTS for laccase) released per unit of leaf DM and time (h). Values are means and standard errors $(n=3)$, and significant differences between conditions for each week are shown by brackets with asterisks and superscript (n.s. when not significant, $\mathrm{a} \neq \mathrm{b}$, Tukey's test, $P<0.05$ ).

Figure 5: Redundancy analysis (RDA) performed on upstream and downstream samples for the whole experiment $\left(\mathrm{RDA}_{\mathrm{UpDw}}, 1\right)$ and in all samples after translocation $\left(\mathrm{RDA}_{\text {Transloc }}, 2\right)$. Both RDA displays biological variables (bold and solid lines) constrained by environmental ones (dashed lines). Only variables that significantly explained the response of leaf-associated fungal communities to physical and chemical parameters are shown (Permutation test, $P<$ 0.05). Biological variables are composed of phenol oxidase (PhOx), peroxidase (Perox) and laccase (Lacc) activities, ergosterol concentration (Ergo) and band richness (Band).

Environmental variables are composed of conductivity (Cond), $\mathrm{pH}$, lignin percentage (Lignin), pesticide toxicity ( $T U$ ), nutrient (Nitrate (NO3), Phosphate (PO4), Inorganic carbon (DIC)) and heavy metals concentrations (zinc (Zn)). 
Figure 1. Rossi et al.
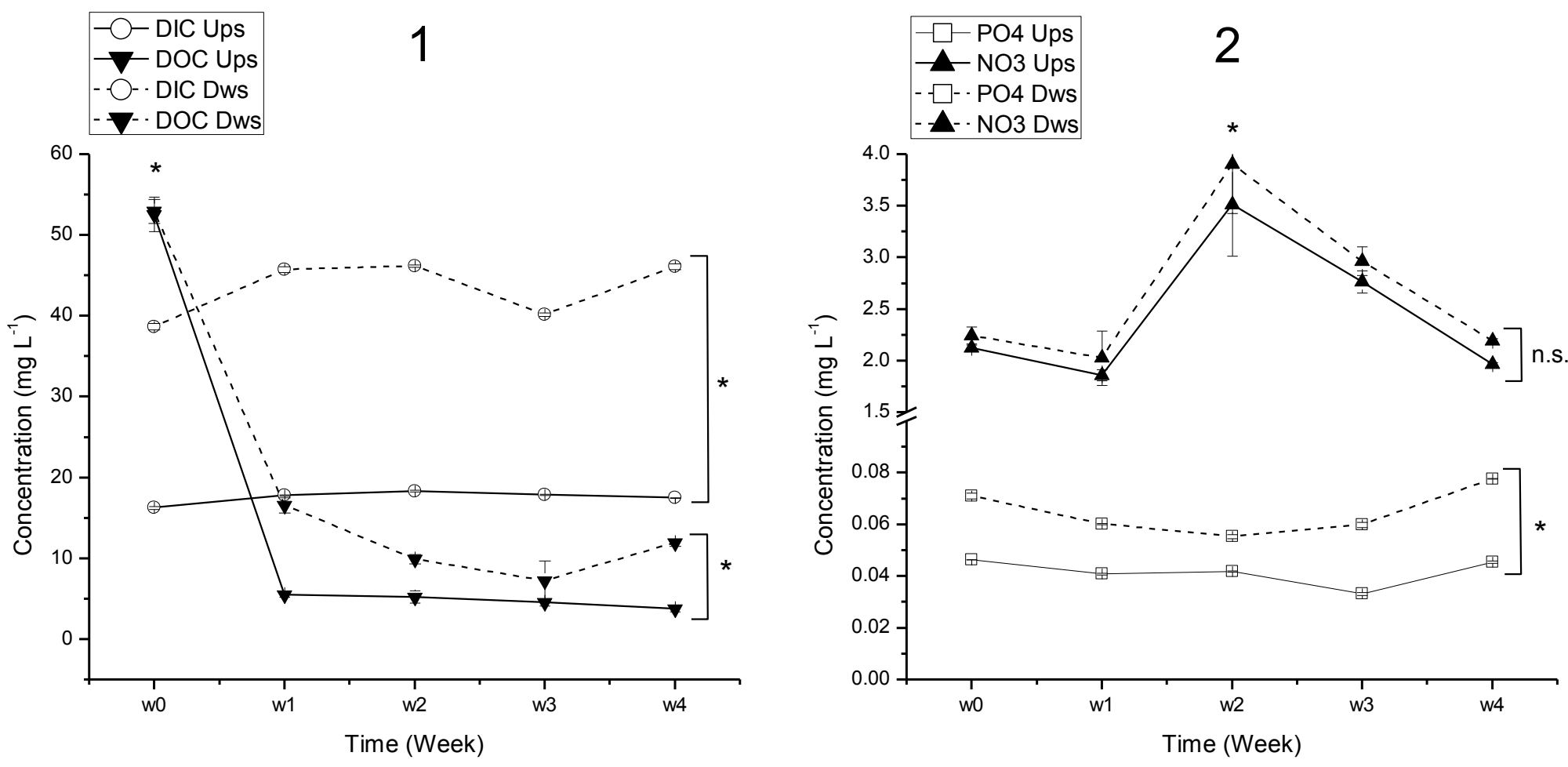
Figure 2. Rossi et al.
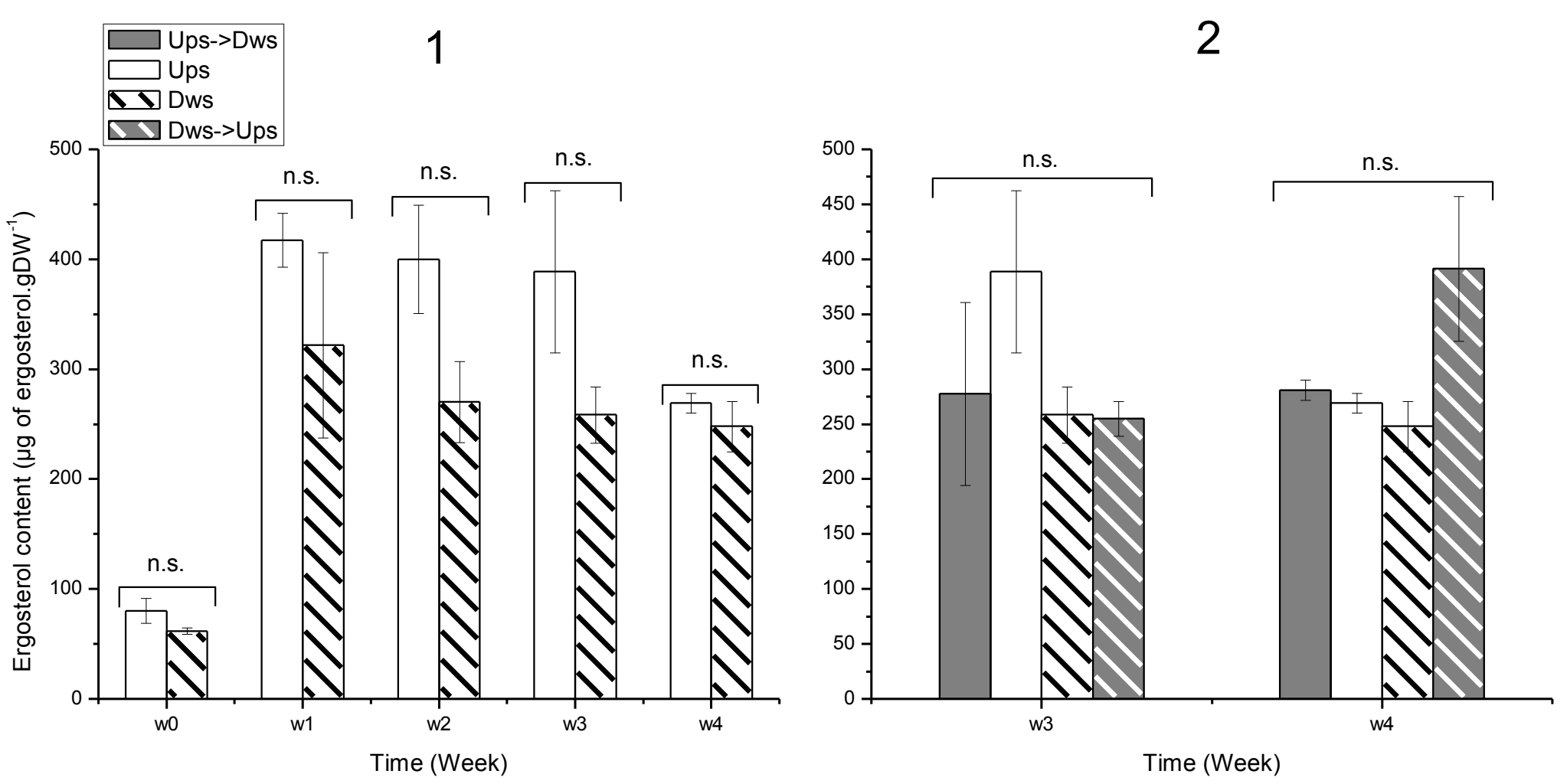
Figure 3. Rossi et al.

\section{Height}

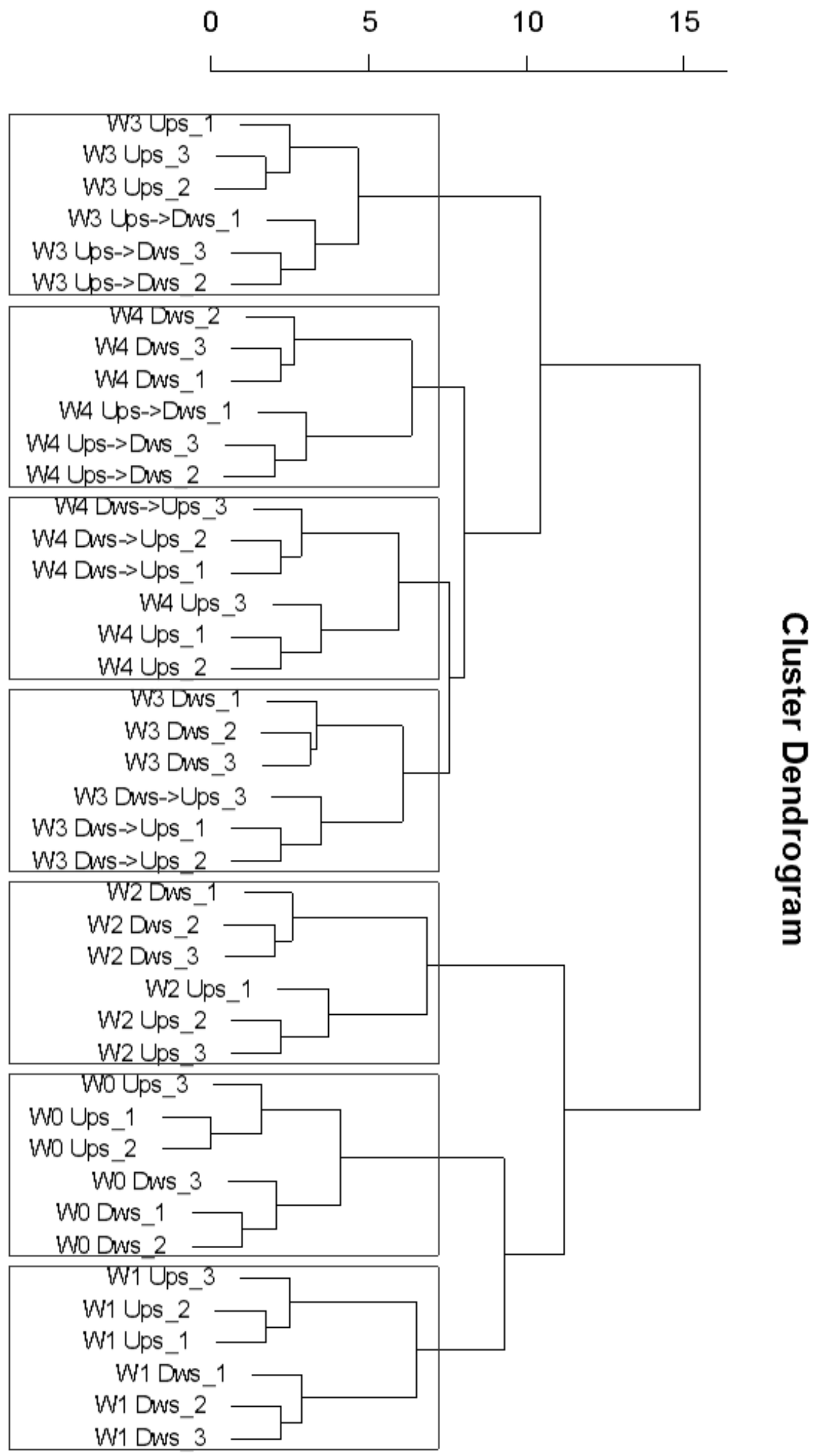


Figure 4. Rossi et al.
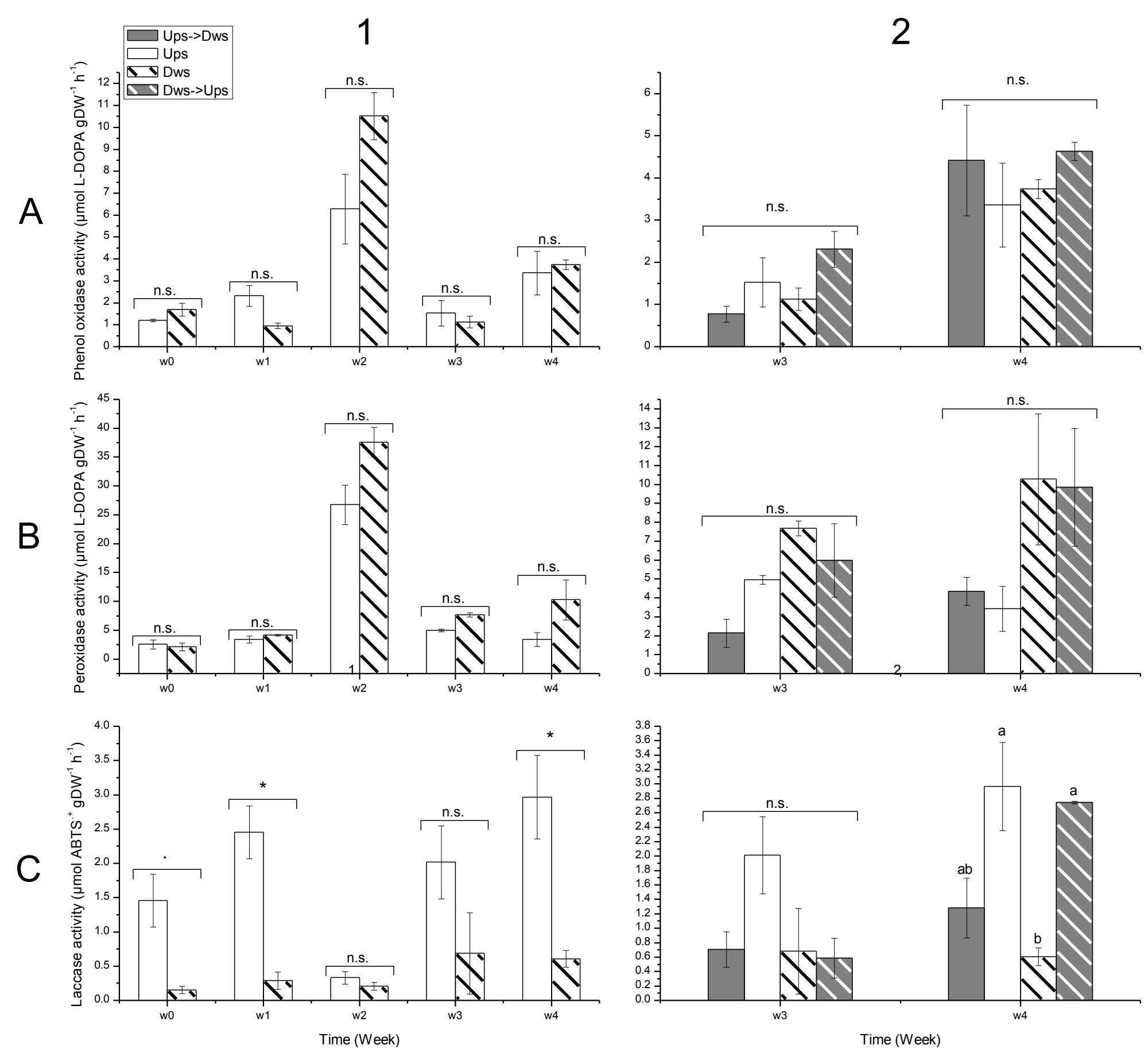
Figure 5.1. Rossi et al.

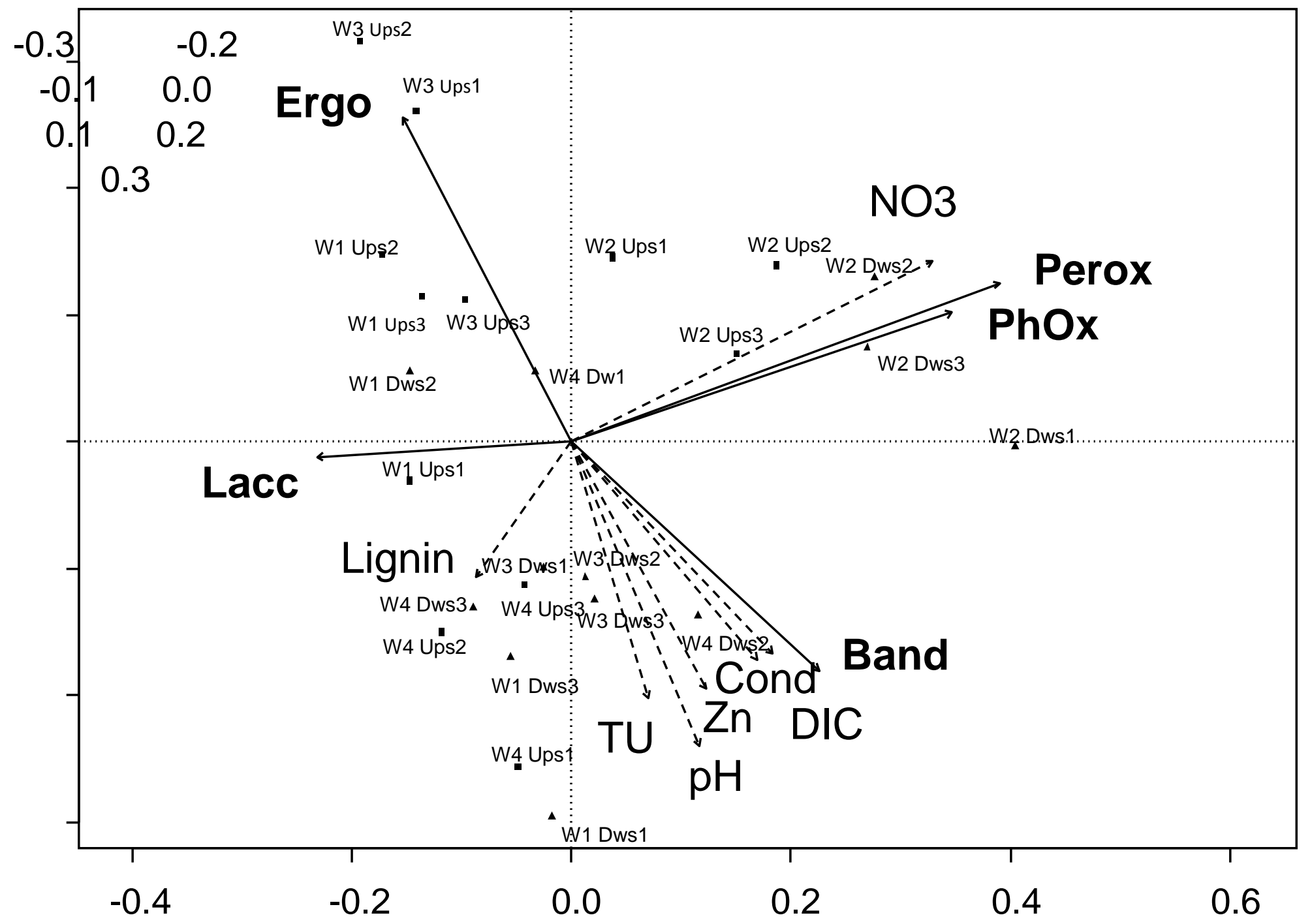

RDA 
Figure 5.2. Rossi et al.

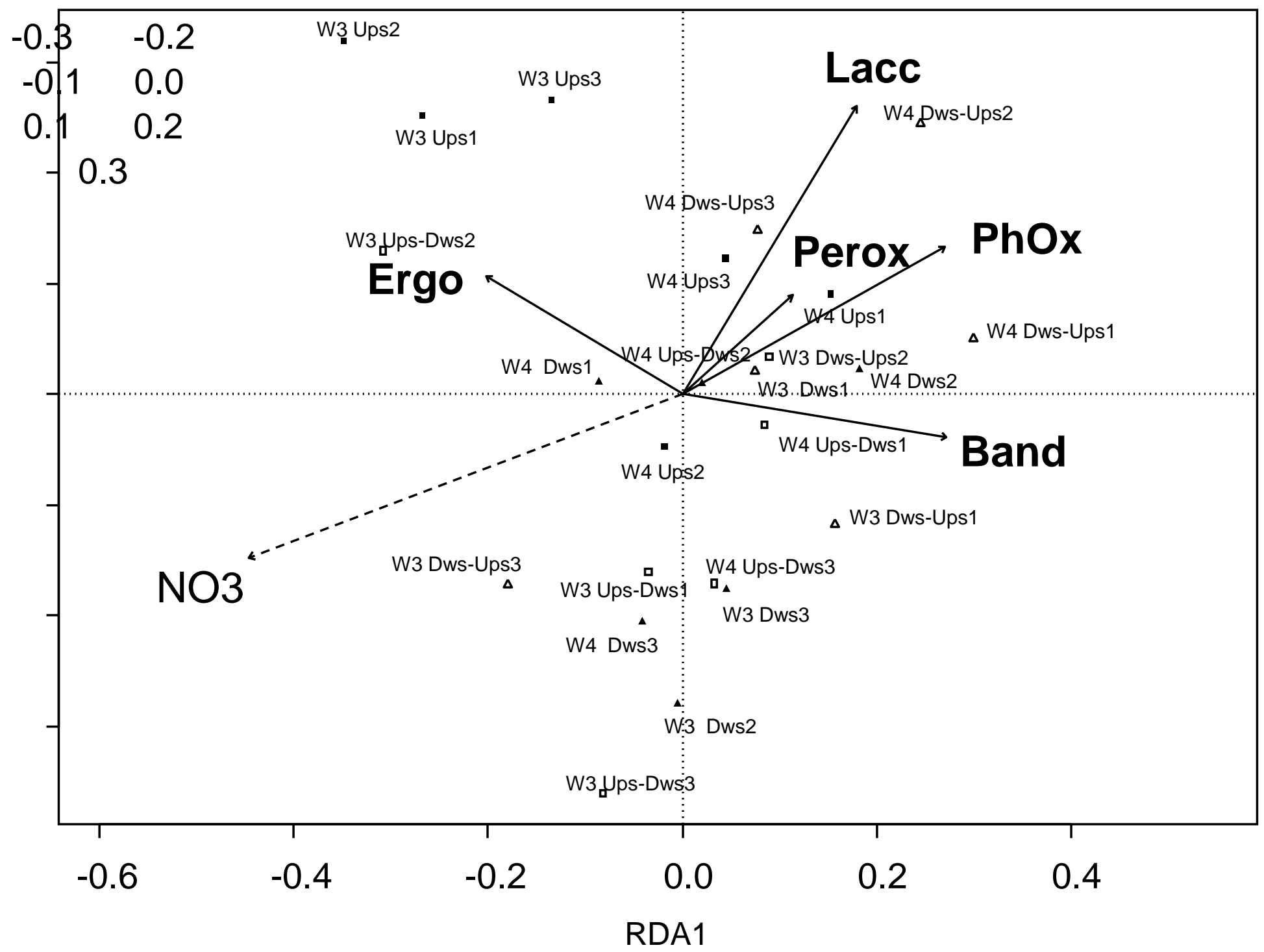

